\title{
Water Quality of River Kosi and Rajera System at Rampur (India): Impact Assessment
}

\author{
Ashish Kumar, ${ }^{1}$ and Yogendra Bahadur ${ }^{2}$ \\ ${ }^{1}$ Department of Chemistry, Agra College, Agra 282002, India \\ ${ }^{2}$ Department of Chemistry, Bareilly College, Bareilly 243001, India \\ Correspondence should be addressed to Ashish Kumar; akr2509@gmail.com
}

Received 2 March 2012; Revised 5 June 2012; Accepted 14 June 2012

Academic Editor: Stefan Tsakovski

Copyright (c) 2013 A. Kumar and Y. Bahadur. This is an open access article distributed under the Creative Commons Attribution License, which permits unrestricted use, distribution, and reproduction in any medium, provided the original work is properly cited.

River Kosi, an important tributary of river Ramganga, is one of the important rivers of Uttaranchal and Uttar Pradesh After traveling for about $100 \mathrm{kms}$ in lower Himalayas with higher velocity, it emerges at Ramnagar in Indo-Gangetic plains. Here, the major portion of city sewage is discharged into it. Then, it flows through the famous rice belt area of Kashipur, where a number of polluting industries discharge their highly polluted effluents into it. To determine the extent of pollution in downstream district Rampur, a study was conducted. The aim of this study was to evaluate the effect of dilution caused by the merger of river Rajera with Kosi River. For this samples, were collected from three stations and analyzed for various parameters for the period of one year. The study revealed higher levels of industrial pollution as compared to domestic pollution. It also shows the alleviating effects of dilution caused by the merger of river Rajera.

\section{Introduction}

The river Kosi is one of the major tributaries of river Ramganga and is one of the important river of northern part of Uttar Pradesh and Uttranchal. The major areas, which are parts of Kosi river basin, are Tota-aam and Garajiya in Almora, city Ramnagar (Distt. Nainital), Kashipur (Distt. Udhamsingh Nagar), Dadiyal, Swar, Lalpur, and city Rampur. In terms of economic importance, the area lying on the banks of the river that is, from Ramnagar to Rampur is renowned as Rice Belt and amongst the most prosperous agricultural regions for various products since centuries. However, owing to the rapid development of local economy in last decade, the river is under severe pressure from various anthropogenic activities [1].

The river Kosi originates from village Budha Peenath of Kausani region of district Almora (UK). After traveling a distance of about $100 \mathrm{~km}$ in lower Himalayas with higher velocity, it emerges at Ramnagar in Indo-Gangetic Plains, after which the velocity reduces considerably. In the initial stretch through the Shivalik range of Himalayas, it takes water from a number of major streams, and a major portion is diverted into a canal for irrigation purposes. After Ramnagar, it flows through the famous rice-belt area of Kashipur, where a number of polluting industries discharge their highly polluted effluent into it.

The river has a masonry dam at Lalpur, and most of the canals, which irrigate the major portion of the district, are dependent on its water. During lean periods, no discharge is released down stream of Lalpur dam, and in stretches the river becomes nearly dry. The river recharges due to ground water sources and its tributary river Rajera, which meets the Kosi at village Pranpur downstream of city Rampur. After this city, the river traverses a distance of around $50 \mathrm{~km}$ and meets river Ramganga. The total length of the river is about $240 \mathrm{~km}$ (Figure 1(a)).

In order to achieve sustainable water quality, it is important to assess seasonal variations in water quality and to assess the impact of merger of Rajera on the overall water quality of the river Kosi in the study zone [2]; this is the aim of this study. 


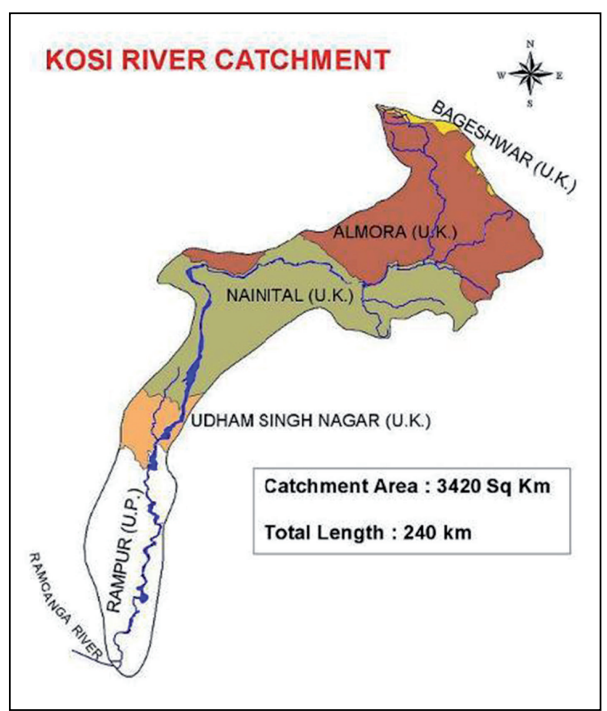

(a) Map-1

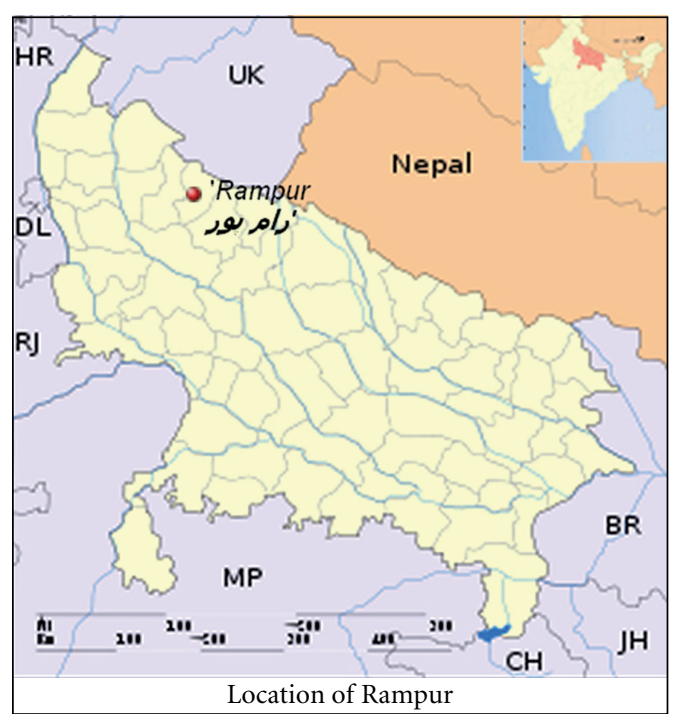

(b) Map-2

Figure 1

\section{Materials and Method}

2.1. Source of Pollution. At Kashipur, apart from domestic waste, a large number of industrial units dump their toxic wastes into the river Kosi causing sever pollution [3]. Large quantities of fertilizers and pesticides are used for agricultural purposes in the river basin and particularly during rains or while flooding the fields for rice; the run off/excess water finds its way to the river. However, during nonmonsoon period, the magnitude of carry over to the river is not significant [4]. In addition to the above, a part of cattle generated wastes and agricultural resides also reaches the river during monsoons as runoff. It is estimated that $10-15 \%$ of the nutrients added to the soil in the form fertilizers reaches the surface water system [5].

During survey, it was observed that rural areas are situated on both the sides of Kosi, which are engaged mainly in the agriculture and cattle farming. These cattle while wading in the river transfer fecal matter and other types of pathogens in the river. Also the various movement and activities of the cattle inside the water disturb the river bed where the pollutants are settled in the form of sludge. This ultimately deteriorates the quality of the river water to a considerable extent. All these constitute the nonpoint pollution sources $[6,7]$.

2.2. Study Area. The area under study is the basin of river Kosi, which pass through district Rampur, Uttar Pradesh (Figure 1(b)). It is located between longitudes $78^{\circ} 54^{\prime \prime}$ to $69^{\circ} 28^{\prime \prime} \mathrm{E}$ and latitude $28^{\circ} 25^{\prime \prime}$ to $29^{\circ} 10^{\prime \prime} \mathrm{N}$. It covers $2,367 \mathrm{Km}^{2}$ areas. The people of this area work mainly in agriculture and industries in nearest places. The Kosi River water is used for agriculture, domestic use, and drinking purposes. In order to study the effects of various anthropogenic activities on the water quality of river Kosi, an area next to city Rampur was selected. In the study zone, a smaller river Rajera

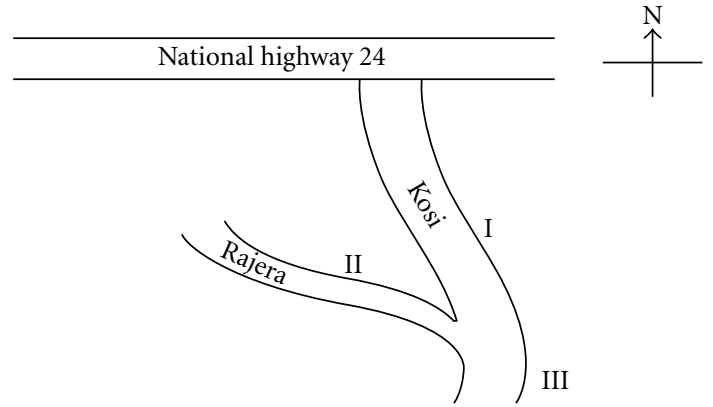

FiguRE 2

merges with river Kosi. The present study also underlines the alleviating effects of dilution on the overall river water quality.

2.3. Sampling Sites and Sample Study. An extensive study was carried out on the physicochemical and bacteriological quality of water of the rivers Kosi and Rajera. All three sampling stations were fixed as given below in map for regular collection of water samples at the rates of once every month for one year. The overall study period was divided into three seasons mainly Winter (Nov-Feb), Summer (Mar-June), and Rain (July-Oct).

Sample Station I: River Kosi before merger.

Sample Station II: River Rajera before merger.

Sample Station III: River Kosi after joining River Rajer.

All the samples were collected in clean white plastic containers. Parameters like $\mathrm{pH}$, temperature, conductivity, and Dissolved Oxygen (D.O.) were estimated on the spot. Rest of the parameters was analyzed as per standard methods $[8,9]$ (see Figure 2). 
TABLE 1: Mean values of physicochemical and biological parameters of River Kosi and River Rajera at Rampur showing seasonal variations.

\begin{tabular}{|c|c|c|c|c|c|c|c|c|c|c|c|c|}
\hline & \multicolumn{3}{|c|}{ Temperature $\left({ }^{\circ} \mathrm{C}\right)$} & \multicolumn{3}{|c|}{$\mathrm{pH}$} & \multicolumn{3}{|c|}{ Total solids (mg/L) } & \multicolumn{3}{|c|}{ Conductivity $(\mu-\mathrm{mho} / \mathrm{cm})$} \\
\hline & $\mathrm{W}$ & S & $\mathrm{R}$ & $\mathrm{W}$ & S & $\mathrm{R}$ & $\mathrm{W}$ & S & $\mathrm{R}$ & $\mathrm{W}$ & S & $\mathrm{R}$ \\
\hline Station 1 & 19.7 & 34 & 30.9 & 7.7 & 7.5 & 7.5 & 365 & 387 & 386 & 493 & 514 & 445 \\
\hline Station 2 & 20.1 & 33.5 & 30.7 & 7.9 & 7.4 & 7.6 & 325 & 351 & 366 & 461 & 482 & 421 \\
\hline \multirow[t]{3}{*}{ Station 3} & 18.9 & 33.4 & 30.5 & 7.8 & 7.3 & 7.5 & 341 & 347 & 372 & 479 & 485 & 430 \\
\hline & \multicolumn{3}{|c|}{ Turbidity (NTU) } & \multicolumn{3}{|c|}{ Hardness (mg/L) } & \multicolumn{3}{|c|}{ Chloride (mg/L) } & \multicolumn{3}{|c|}{ Alkalinity (mg/L) } \\
\hline & $\mathrm{W}$ & S & $\mathrm{R}$ & W & S & $\mathrm{R}$ & $\mathrm{W}$ & S & $\mathrm{R}$ & $\mathrm{W}$ & S & $\mathrm{R}$ \\
\hline Station 1 & 32 & 41 & 75 & 205 & 209 & 199 & 25.3 & 21.0 & 18.8 & 195 & 158 & 111 \\
\hline Station 2 & 25 & 34 & 73 & 189 & 188 & 184 & 21.4 & 19.0 & 18.1 & 157 & 131 & 91 \\
\hline \multirow[t]{3}{*}{ Station 3} & 29 & 36 & 74 & 211 & 207 & 205 & 23.8 & 20.0 & 18.2 & 197 & 153 & 98 \\
\hline & \multicolumn{3}{|c|}{ D.O. (mg/L) } & \multicolumn{3}{|c|}{ B.O.D. (mg/L) } & \multicolumn{3}{|c|}{ C.O.D. (mg/L) } & \multicolumn{3}{|c|}{ MPN } \\
\hline & $\mathrm{W}$ & S & $\mathrm{R}$ & W & S & $\mathrm{R}$ & $\mathrm{W}$ & S & $\mathrm{R}$ & $\mathrm{W}$ & S & $\mathrm{R}$ \\
\hline Station 1 & 6.7 & 6.8 & 6.3 & 5.9 & 5.7 & 5.8 & 39.0 & 33.0 & 36.0 & 121 & 134 & 190 \\
\hline Station 2 & 6.6 & 6.6 & 6.2 & 6.0 & 5.5 & 5.9 & 36.0 & 32.8 & 33.5 & 115 & 126 & 179 \\
\hline Station 3 & 6.5 & 6.4 & 6.3 & 6.0 & 5.5 & 6.0 & 40.0 & 36.0 & 36.5 & 114 & 129 & 189 \\
\hline
\end{tabular}

W: Winter (Nov. to Feb.), S: Summer (Mar. to Jun.), R: Rainy (Jul. to Oct.).

\section{Result and Discussions}

The physicochemical characteristics of water samples (mean values) at different stations in the three consecutive seasons have been presented in Table 1. As is clear from the table and values of parameters, station I is the most polluted along Kosi river. The colour of water sample was generally light brown along the Kosi, river. However, the intensity of colour diminishes at station III. This can be attributed to the merger of river Rajera and subsequent dilution of Kosi river water [10]. It is also clear from Table 1 that parameters like conductivity show decreased values during rainy season which can be attributed to dilution by rain water [11].

The water samples gives out faint aroma, which expresses a mixed odour of various chemicals, used as raw materials in industrial units. The odour is also caused by decomposing plant and animal debris and domestic sewage [12]. However, during rainy season no characteristic odour is found due to the dilution [5]. Temperature is an important factor for its effect on certain chemical reactions taking place in organisms inhibiting aquatic media and also on the soil-water interphase.

A cursory inspection of the observed turbidity values shows that water at station I is most turbid throughout the study period. This may be attributed to the lower amount of water. The turbidity at station III was found to decrease, may be due to the dilution effect of river Rajera. The electrical conductivity decreases from station I to station III. This can be attributed to the decreased Total Dissolved Solids (TDS) which also follows the same trend [10].

The relative higher values of Chemical Oxygen Demand (COD) as compared to Biochemical Oxygen Demand (BOD) indicate higher level of industrial pollution caused by industrial units situated due north in Kashipur [13].

Calcium and magnesium are largely responsible for the hardness of water. The acidity of water used for industrial purpose is controlled by the use of lime. Here all the three
TABLE 2: WQI range for different classes of beneficial use.

\begin{tabular}{lcc}
\hline Class of the river & Limits of W.Q.I & Condition of river \\
\hline I & 90 and above & Excellent \\
II & Between $65 \& 89$ & Good \\
III & Between $35 \& 64$ & Satisfactory \\
IV & Between $11 \& 34$ & Poor \\
V & 10 and below & Unacceptable \\
\hline
\end{tabular}

have higher values at station I, which decreases as river flows to station III [14].

It is clear that Most Probable Number (MPN) count is highest at station I in all three seasons, which indicates severe pollution. In general, the values are maximum during the rainy season; hence coliforms are maximum in river water during this season. On the other hand, the minimum values are observed in winter season; therefore, the coliform is found least in this season [1].

3.1. Water Quality Index (WQI). The river water quality can be assessed using various methods including multivariate analysis [15]. Another method is WQI, here with the help of individual values of a number of variables along with the relative importance of each variable, the water quality for a given use/class of river (Table 2) can be put in terms of a single number called the Water Quality Index (WQI). Though various expressions for WQI determination were given earlier, a simplified expression (1) for WQI is utilized here [16]. The WQI values for three stations (Table 3, Figure 3) are also in accordance with the above results. This clearly shows the impact of relatively clean water of river Rajera, which results in the higher values of WQI at station III as compared to station I [17]

$$
\mathrm{WQI}=\left[\prod_{i=1}^{i=n} f_{i}\right]^{1 / n} \times 100,
$$


TABLE 3: Water quality index of river Kosi and river Rajera at Rampur showing seasonal variations.

\begin{tabular}{lccc}
\hline & W & S & R \\
\hline Station 1 & 47 & 43 & 44 \\
Station 2 & 47 & 44 & 43 \\
Station 3 & 47 & 43 & 44 \\
\hline
\end{tabular}

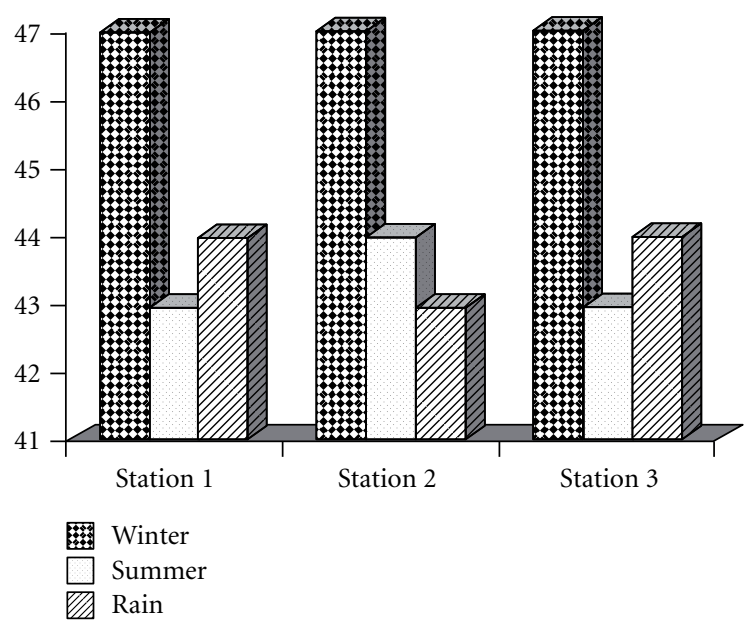

FIgURE 3: WQI for river Kosi \& Rajera.

where $f$ is sensitivity function and $n$ is the number of relevant parameters used.

\section{Conclusion}

River water pollution is not only an aesthetic problem, but a serious economic and public health problem as well. Regular monitoring of the water quality is thus required to assess the condition of river water. This is helpful in saving the river from further degradation. From the above study it is cleat that the water of river Kosi is very much polluted but still can be used for agriculture and fish culture. But there is an urgent need to control the further deterioration of river water quality. It also underlines the need to control the quality and quantity of the waste water that is being discharged into the river, so as to maintain the desired quality of water.

\section{References}

[1] A. Kumar and Y. Bahadur, "Physico-chemical studies on the pollution potential of river Kosi at Rampur (India)," World Journal of Agricultural Sciences, vol. 5, no. 1, pp. 01-04, 2009.

[2] H. P. Jarvie, P. M. Haygarth, C. Neal et al., "Stream water chemistry and quality along an upland-lowland rural land-use continuum, South West England," Journal of Hydrology, vol. 350, no. 3-4, pp. 215-231, 2008.

[3] W. Xiaolong, H. Jingyi, X. Ligang, and Z. Qi, "Spatial and seasonal variations of the contamination within water body of the Grand Canal, China," Environmental Pollution, vol. 158, no. 5, pp. 1513-1520, 2010.

[4] S. W. Yoon, S. W. Chung, D. G. Oh, and J. W. Lee, "Monitoring of non-point source pollutants load from a mixed forest land use,"
Journal of Environmental Sciences, vol. 22, no. 6, pp. 801-805, 2010.

[5] C. N. Sawyer, P. L. McCarty, and G. F. Parkin, Chemistry for Environmental Engineering, McGraw Hill, New York, NY, USA, 1994.

[6] X. L. Wang, Y. L. Lu, J. Y. Han, G. Z. He, and T. Y. Wang, "Identification of anthropogenic influences on water quality of rivers in Taihu watershed," Journal of Environmental Sciences, vol. 19, no. 4, pp. 475-481, 2007.

[7] S. Chandra, A. Singh, P. K. Tomar, and A. Kumar, "Evaluation of physicochemical characteristics of various river water in India," E-Journal of Chemistry, vol. 8, no. 4, pp. 1546-1555, 2011.

[8] APHA, AWWA, and WPCF, Standard Methods for Examination of Water and Waste Water, APHA, 20th edition, 1998.

[9] R. K. Trivedy and P. K. Goyal, Chemical and Biological Methods for Water Pollution Studies, Enviro-Media Karad, 1996.

[10] Y. Bahadur and R. Chandra, "Monitoring the quality of River Ramganga waters at Bareilly," Pollution Research, vol. 15, no. 1, pp. 31-33, 1996.

[11] J. J. Rothwell, N. B. Dise, K. G. Taylor et al., "A spatial and seasonal assessment of river water chemistry across North West England," Science of the Total Environment, vol. 408, no. 4, pp. 841-855, 2010.

[12] S. Gupta, M. Bhatnagar, and R. Jain, "Physico-chemical characteristics and analysis of $\mathrm{Fe}$ and $\mathrm{Zn}$ in tubewell water and sewage water of Bikaner City," Asian Journal of Chemistry, vol. 15, no. 2, pp. 727-732, 2003.

[13] K. S. Pande and S. D. Sharma, "Studies of toxic pollutants in Ramganga river at Moradabad India," Environmental Geology, vol. 1, no. 2, pp. 93-96, 1998.

[14] D. S. Bhargava, "Nature and the Ganga," Environmental Conservation, vol. 14, no. 4, pp. 307-318, 1987.

[15] S. Yerel, "Water quality assessment of Porsuk River, Turkey," EJournal of Chemistry, vol. 7, no. 2, pp. 593-599, 2010.

[16] D. S. Bhargava, "Expression for drinking water supply standards," Journal of Environmental Engineeringõ American Society of Civil Engineers, vol. 111, no. 3, pp. 304-316, 1985.

[17] D. S. Bhargava, "Use of water quality index for river classification and zoning of Ganga river," Environmental Pollution Series $B$, vol. 6 , no. 1, pp. 51-67, 1983. 

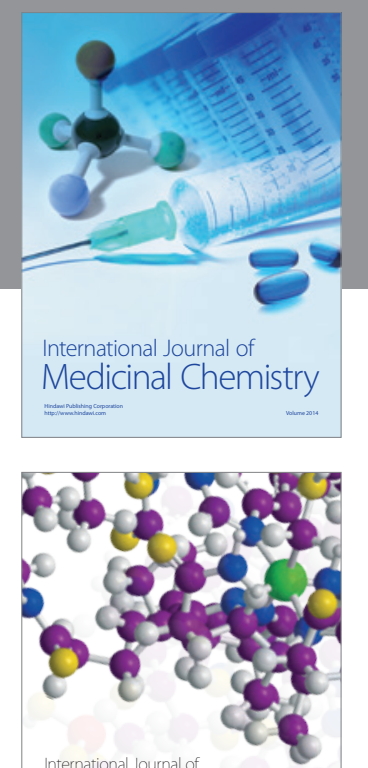

\section{Carbohydrate} Chemistry

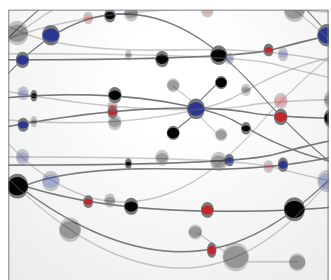

The Scientific World Journal
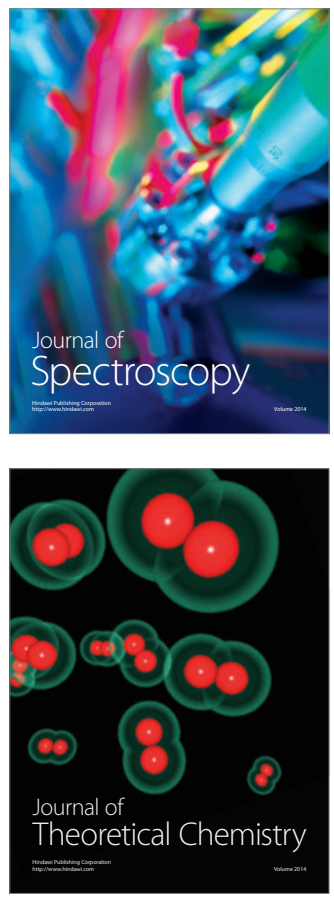
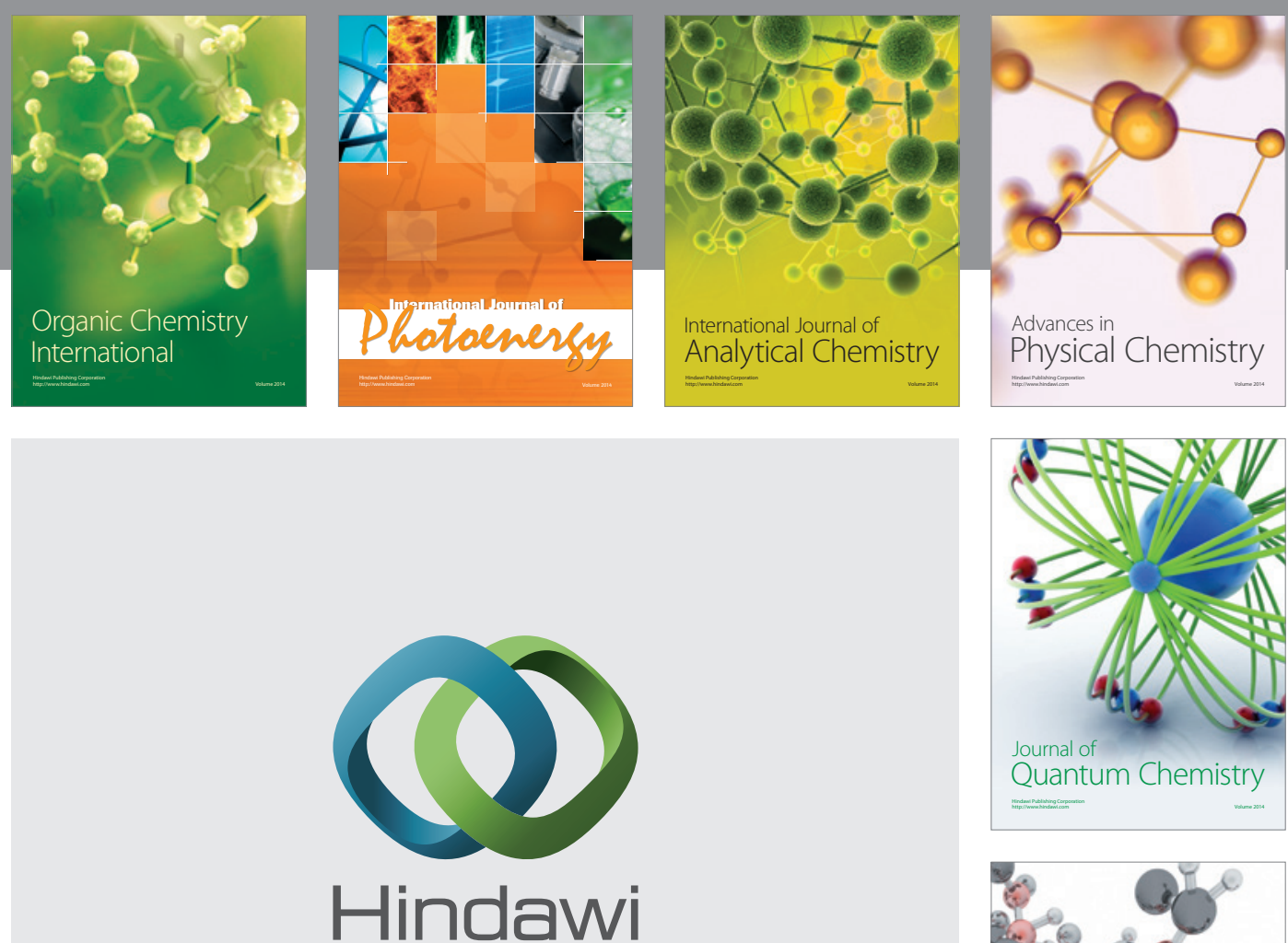

Submit your manuscripts at

http://www.hindawi.com

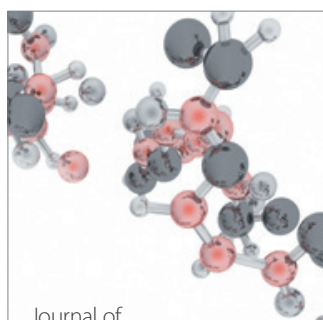

Analytical Methods

in Chemistry

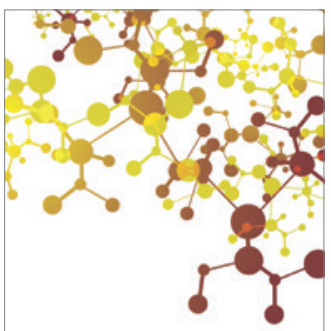

Journal of

Applied Chemistry

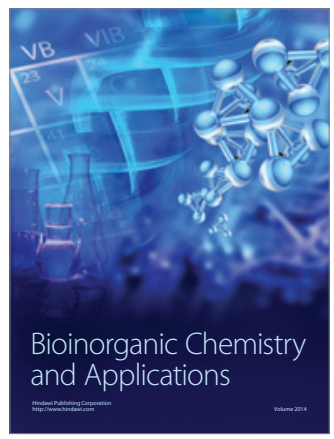

Inorganic Chemistry
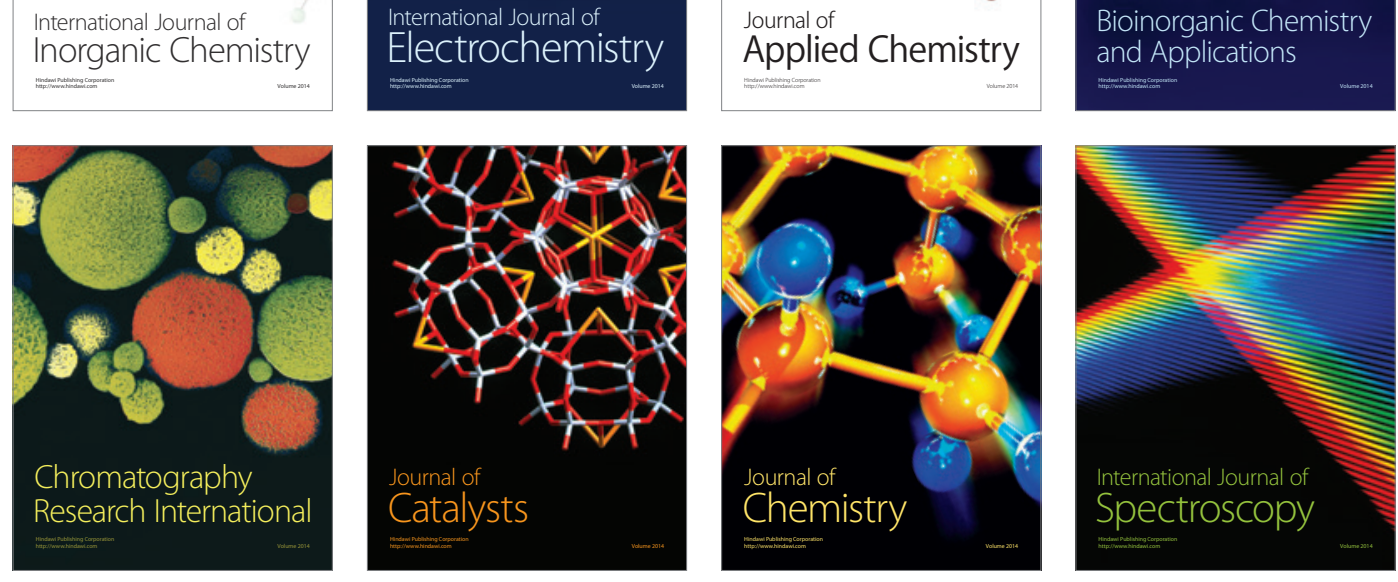